\title{
Article
}

\section{Writing in Graduate School: A Found Poem}

Andrea R. Olinger ${ }^{1}$

Department of English, University of Louisville

\section{Abstract}

The author presents and reflects on a found poem she composed from the final papers of students in her multidisciplinary graduate writing class.

\section{Introduction}

\section{Writing in Graduate School: It Requires Much More Than Words on Paper by the students of English 599, spring 2015}

\section{Introduction of the imperfect past}

I have always been afraid of writing

I would say it frightened me at the beginning

Avoid anything dangerous

Careful and cautious

\section{Negative mandates}

Learn our language

hostile behavior, anxiety felt

Use of the subjunctive for aspiration and desire

There is no end to the responsibilities

State your conclusion or demand, then support it with law choking in a rectangular warehouse

Do not be fooled by those who claim to be forward thinking and call any work but their own old fashioned turn blue

Follow all of these rules to the letter sinking into the water to kill herself

\section{Introduction of the future}

Your brain always has a translation process whenever you speak, listen, read or write 
Volume 28, 2018

http://journals.sfu.ca/cjsdw

This study will be the first of its kind

One must learn to write certain types of documents

When the fungus infects the host plant, the fungal genes will modify, take agency over flesh

The vector was successfully transferred into yeast AH109

\section{Lesson 4A Regular verbs ending with Ar}

Those without "the bug," like wild friends, will be shipped out immediately

Those with "the bug," write what music you will

her writing will be in good shape the uncanny lies within

Figure 1. Writing Graduate School: It Requires Much More Than Words on Paper

\section{Explanatory Statement: An Instructor at Play}

I teach a writing class for graduate students and advanced undergraduates in multiple disciplines, and I constructed this found poem the first year I taught the class, as I began responding to students' final projects. Impressed by the array of such disparate disciplinary styles and genres, I became curious about what would happen if they were assembled and juxtaposed. Could they be made to communicate something new?

As I read students' papers, I opened a separate document and began copying and pasting words, phrases, and sentences that sounded unusual or moving. Source material included a microbiology thesis proposal, an industrial engineering journal article, a review of a Spanish language textbook, blog posts for music theory students, literacy narratives, a report on legal writing, and an analysis of the graphic novel Black Hole (Burns, 2005), in which teenagers catch a mysterious disease called "the bug." I admit that hunting for lines added delight to the process, and I often found myself giggling as I worked. Once I had read and responded to every paper, I turned to my "found" document. I pruned and arranged the linguistic bits into stanzas, headings, and a title so they told a story about writing in graduate school. On the last day of class, I distributed copies of the poem and read it aloud. Students, each of whom was represented at least once, enjoyed figuring out which lines were theirs.

With the poem, I aimed to paint a humorously disturbing picture of acculturation into graduate writing through the extended metaphor of writing proficiency as a disease or virus. In the first section, a narrator confesses feeling fear and caution about this immersion. The second section contains directives about rule-following (e.g., "Learn our language"), along with the embodied effects of these directives (e.g., "choking in a rectangular warehouse," "turn blue"). The third section depicts a "translation process" - analogized to a "fungus infect[ing] the host plant" - in which the 
Volume 28, 2018

http://journals.sfu.ca/cjsdw

subject's writing begins to change, indicated by the use of the rhetorical move "This study will be the first of its kind." The final section identifies two groups: (1) writers who do not have "the bug," i.e., unsuccessful writers, who will be "shipped out," and (2) writers who do have "the bug," i.e., successful writers, who "will be in good shape." Yet readers are meant to feel unsettled by the latter group because, we are told, with the italics connoting a whisper, "the uncanny lies within." The writer is forever changed by the implantation of this alien form.

I do not endorse this extended metaphor, of course; the poem is designed to be silly. At another level, however, the construction of a found poem out of texts from different disciplines and genres is literal proof that interactions with other disciplines can be valuable and productive. Had the idea for the poem not come to me so late, I might have invited students to dip into the corpus of final papers themselves to compose and share their own found poetry. Such a poem could allow students, at the semester's end, to express their own feelings about graduate school or their academic and professional trajectories. Moreover, the heterogeneous source material would nicely embody the effects of participating in the classroom community: the idea that each member of the class learns from, and leaves an imprint on, everyone else.

The more general principle at work, however, is that thinking about your research through the language or lens of another discipline, genre, or medium can be a way to get unstuck or develop new ideas. This concept drives many different writing strategies, from Cargill and O'Connor's (2013) recommendation to turn published texts into sentence skeletons to Sword's (2012) exercises of incorporating figurative language into academic writing to other creative strategies for working with data, such as writing about your research in haiku form (e.g., Janesick, 2015) or depicting your findings through dance ("Dance Your PhD”).

Disciplinary juxtapositions can also be a way to envision or forge interdisciplinary research partnerships. I saw this process in action at a grant-writing institute for graduate students hosted by Susanna Cornett and Teresa Wilkins, grant manager specialists for the College of Arts and Sciences at my university. On the first day, students were asked to walk around the room and introduce themselves to one another. At each meeting, students had to share their project idea and, with their partner, develop an idea for a collaborative grant. Many of the results were zany, but fruitful pairings also emerged.

Whether you create a found poem for your own amusement, invite your students to do so, or try out other activities, my overall advice is to welcome interactions with other disciplines (and genres 
Volume 28, 2018

http://journals.sfu.ca/cjsdw

and media), whether at the sentence level or the human one. Doing so may feel strange, but the results may enlighten — and, at the least, they will delight.

\section{Endnotes}

1. Correspondence may be addressed to andrea.olinger@louisville.edu.

\section{References}

Burns, C. (2005). Black hole. New York, NY: Pantheon.

Cargill, M., \& O'Connor, P. (2013). Writing scientific research articles: Strategy and steps (2 $2^{\text {nd }}$ ed.). West Sussex, Eng.: Wiley-Blackwell.

"Dance Your PhD." (2017). Science. Retrieved from http://www.sciencemag.org/projects/danceyour-phd

Janesick, V. J. (2015). "Stretching" exercises for qualitative researchers (4th ed.). Thousand Oaks, CA: SAGE Publishers.

Sword, H. (2012). Stylish academic writing. Cambridge, MA: Harvard University Press. 